\title{
GEOPOLYMER MORTAR INCORPORATING HIGH CALCIUM FLY ASH AND SILICA FUME
}

\author{
V.C.PRABHA ${ }^{1}$, V.REVATHI ${ }^{2}$
}

\begin{abstract}
An attempt was made in the present work to study the compressive strength and microstructure of geopolymer containing high calcium fly ash (HCFA) and silica fume. Concentration of sodium hydroxide solution 8M, 10M, $12 \mathrm{M} \& 14 \mathrm{M}$, liquid to binder ratio 0.5 and sodium hydroxide to sodium silicate ratio 2.5 were selected for the mixes. Geopolymer mortar test results indicated that the mix with $40 \%$ silica fume by the weight of HCFA yielded higher compressive strength under ambient curing. The XRD pattern typically shows the major portion of amorphous phase of geopolymer. The existence of C-A-S-H gel, N-A-S-H gel and hydroxysodalite gel products were observed through SEM which developed dense microstructure and thus enhanced strength of HCFA and silica fume geopolymer.
\end{abstract}

Keywords: geopolymer mortar, compressive strength, ambient curing, High calcium fly ash, Silica fume

\section{INTRODUCTION}

The manufacture of cement causes emission of carbon-di-oxide into the atmosphere which results in environmental pollution. The increasing demands on the strength and durability characteristics of cement concrete prompts to add additives or admixtures or both for specific purposes. Geopolymer, an alternative binder produced from strong alumina silicate reactive materials and highly concentrated aqueous alkali hydroxide or silicate solution has potential to lower the significant carbon footprint of cement concrete [1-3].

\footnotetext{
${ }^{1}$ K.S.R College of Engineering, Dept. of Civil Engineering, Tamil Nadu -637215, India, e-mail: prabhacsamy@gmail.com

${ }^{2}$ K.S.R College of Engineering, Dept. of Civil Engineering, Tamil Nadu -637215, India, e-mail: revthiru2002@yahoo.com
} 
Materials like fly ash, GGBS, bottom ash, silica fume, metakaolin, rice husk ash etc. could be used as alumina silicate reactive materials [4-7]. Geopolymer made of using class F fly ash and GGBS are relatively common and acknowledged in many places $[8,9]$. The most commonly used alkaline activators in geopolymer concrete are combinations of $\mathrm{NaOH}$ and $\mathrm{Na}_{2} \mathrm{SiO}_{3}$ solutions. It has been established that $\mathrm{NaOH}$ possesses greater capacity to liberate silicate and aluminate monomers [10]. Usually, this alkaline activator is prepared by mixing water, $\mathrm{NaOH}$ pellets and $\mathrm{Na}_{2} \mathrm{SiO}_{3}$ solution. Further different alkalis mixtures or other alkali metal systems are being used to obtain required strength and durability. It is important that the solution strictly must be in concentration form to avoid the crystallization of zeolite as the end product rather than an amorphous geopolymer [11, 12]. The compressive strength of geopolymer depends on the type of alumina silicate material and its particle fineness. The fine particles make higher discharge of silica and alumina in the alkali environment and leads to a higher strength geopolymer [13].

The compressive strength is higher for oven drying as compared to the specimens left in ambient curing $[14,15]$. Ambient cured specimens gained their strength without elevated heating mainly because of the presence of high calcium content which has the ability to harden at ambient temperature. It is observed that the strength of the geopolymeric gel, interfacial bonding between the geopolymeric gel and aggregate determine the compressive strength [16]. Previous study also pointed out that crystalline $\mathrm{C}-\mathrm{S}-\mathrm{H}$ phase is formed at higher calcium concentrations, augmenting the strength. As a result of reactions with strong alkaline activators, the co-existence of geopolymeric gel and calcium silicate hydrate $(\mathrm{C}-\mathrm{S}-\mathrm{H})$ gel resulted in HCFA geopolymer system (Xiaolu Guo et al). However, the strength enhancement of HCFA is not much higher compared to low calcium fly ash in geopolymeric reactions. The geoplymeric reaction of several alumina silicate materials does not participate in same amount of reaction for the same condition. For instance, two types of fly ash perform different reactions. The HCFA geopolymers attain higher strength at early age periods when it is steam cured [17-19]. The geopolymer prepared from silica fume and GGBS is reported to develop improved strength under ambient curing [20]. The inclusion of silica fume into low calcium fly ash geopolymer optimizes the microstructure and yielded higher strength [21-24]. Silica fume significantly reduced the porosity and permeability [25-27].

Besides, there is no study made on high calcium fly ash with the addition of silica fume in geopolymer. This present study aims to look into the compressive strength and micro structural study on addition of silica fume in HCFA geopolymer. 


\section{Materials \& Experimental Program}

\subsection{Materials}

Fly ash was collected from Neyveli Lignite Corporation in Cuddalore district of Tamilnadu. The HCFA was ground to become finer by ball mill for $8 \mathrm{hrs}$. The specific gravity of HCFA was found to be 2.25 . The silica fume used in this study was purchased from Coimbatore. The specific gravity of silica fume used in the study was observed as 2.34 . The river sand with specific gravity of 2.6 and fineness modulus of 2.1 was also used. Alkaline activators chosen were sodium silicate $\left(\mathrm{Na}_{2} \mathrm{SiO}_{3}\right)$ and sodium hydroxide $(\mathrm{NaOH})$. The sodium silicate solution and sodium hydroxide in flakes were procured from Mercury Sakthi enterprises company, Erode. To make the sodium hydroxide solution, flakes (97-98\% purity) were dissolved in tap water. The chemical properties of fly ash and silica fume are presented in Table 2.1.

Table 2.1 Chemical Composition of Fly Ash \& Silica Fume

\begin{tabular}{|c|l|c|c|}
\hline S.No & Chemical composition & Fly Ash & Silica Fume \\
\hline 1. & Silica $\left(\mathrm{SiO}_{2}\right)$ & $63.11 \%$ & $93.67 \%$ \\
\hline 2. & Calcium Oxide $(\mathrm{CaO})$ & $17.13 \%$ & $0.31 \%$ \\
\hline 3. & Aluminium Oxide $\left(\mathrm{Al}_{2} \mathrm{O}_{3}\right)$ & $19.58 \%$ & $0.83 \%$ \\
\hline 4. & Magnesium Oxide $(\mathrm{MgO})$ & $0.24 \%$ & $0.84 \%$ \\
\hline 5. & Iron Oxide $\left(\mathrm{Fe}_{2} \mathrm{O} 3\right)$ & $5.03 \%$ & $1.30 \%$ \\
\hline 6. & Sodium Oxide $\left(\mathrm{Na}_{2} \mathrm{O}\right)$ & $0.29 \%$ & $0.40 \%$ \\
\hline 7. & Potassium Oxide $\left(\mathrm{K}_{2} \mathrm{O}\right)$ & $0.84 \%$ & $1.10 \%$ \\
\hline 8. & Loss ofIgnition $(\mathrm{L} . \mathrm{O} . \mathrm{I})$ & $1.55 \%$ & $2.10 \%$ \\
\hline
\end{tabular}

\subsection{PROPORTION}

The present study has High Calcium Fly Ash (HCFA) and silica fume as the source material for the geopolymer mortar. In this experiment, it is proposed to mix HCFA with silica fume contents $0 \%$, $20 \%, 40 \%, 60 \%$ and $80 \%$ by total weight of the dry fly ash. Twenty numbers of mixes were studied. All geopolymer mortars were made with sand to fly ash ratio of 1:3. Liquid to binder ratio was 0.5 . Sodium silicate to sodium hydroxide ratio was kept as 2.5 . The molarity of $\mathrm{NaOH}$ varied from $8 \mathrm{M}$ to $14 \mathrm{M}$ at an interval of $2 \mathrm{M}$. The following mix identity is used for the geopolymer mortar of 
various mix propositions. 'F' represents HCFA, 'S' identifies Silica Fume, and the suffix value of the numerical indicates the percentage of silica fume in the total weight of source material. The beginning numerical represents molar concentration. For example in ' $8 \mathrm{FS}_{0}$ ' starting letter ' 8 ' indicates $8 \mathrm{M}$ concentration of $\mathrm{NaOH}$. Various mixes combinations of HCFA geopolymer mortar used in the present study are given in Table 2.2 .

Table 2.2. Mix Proportions of High Calcium Geopolymer mortar with Silica Fume (Quantity of materials in $\mathrm{kg} / \mathrm{m}^{3}$ )

\begin{tabular}{|c|c|c|c|c|c|c|c|c|}
\hline \multirow{2}{*}{$\begin{array}{l}\text { Sl. } \\
\text { No }\end{array}$} & \multirow[t]{2}{*}{ Mix } & \multirow{2}{*}{$\begin{array}{c}\text { High } \\
\text { Calcium } \\
\text { Fly Ash }\end{array}$} & \multirow{2}{*}{$\begin{array}{l}\text { Replacement } \\
\% \text { of Silica } \\
\text { Fume }\end{array}$} & \multirow{2}{*}{$\begin{array}{l}\text { Silica } \\
\text { Fume }\end{array}$} & \multirow{2}{*}{$\begin{array}{c}\text { Fine } \\
\text { Aggregate }\end{array}$} & \multirow{2}{*}{$\begin{array}{l}\text { Sodium } \\
\text { silicate }\end{array}$} & \multicolumn{2}{|c|}{$\begin{array}{c}\text { Sodium Hydroxide } \\
\text { solution }\end{array}$} \\
\hline & & & & & & & $\mathrm{mol} / \mathrm{L}$ & $\left(\mathrm{kg} / \mathrm{m}^{3}\right)$ \\
\hline 1. & $8 \mathrm{FS}_{0}$ & 568.3 & $0 \%$ & - & 1704.03 & 189.45 & 8 & 91.22 \\
\hline 2. & $8 \mathrm{FS}_{20}$ & 454.6 & $20 \%$ & 113.7 & 1704.03 & 189.45 & 8 & 91.22 \\
\hline 3. & $8 \mathrm{FS}_{40}$ & 340.9 & $40 \%$ & 227.3 & 1704.03 & 189.45 & 8 & 91.22 \\
\hline 4. & $8 \mathrm{FS}_{60}$ & 227.3 & $60 \%$ & 340.8 & 1704.03 & 189.45 & 8 & 91.22 \\
\hline 5. & $8 \mathrm{FS}_{80}$ & 113.6 & $80 \%$ & 454.5 & 1704.03 & 189.45 & 8 & 91.22 \\
\hline 6. & $10 \mathrm{~F} \mathrm{~S}_{0}$ & 568.3 & $0 \%$ & - & 1704.03 & 189.45 & 10 & 91.22 \\
\hline 7. & $10 \mathrm{FS}_{20}$ & 454.6 & $20 \%$ & 113.7 & 1704.03 & 189.45 & 10 & 91.22 \\
\hline 8. & $10 \mathrm{FS}_{40}$ & 340.9 & $40 \%$ & 227.3 & 1704.03 & 189.45 & 10 & 91.22 \\
\hline 9. & $10 \mathrm{FS}_{60}$ & 227.3 & $60 \%$ & 340.8 & 1704.03 & 189.45 & 10 & 91.22 \\
\hline 10. & $10 \mathrm{FS}_{80}$ & 113.6 & $80 \%$ & 454.5 & 1704.03 & 189.45 & 10 & 91.22 \\
\hline 11. & $12 \mathrm{~F} \mathrm{~S}_{0}$ & 568.3 & $0 \%$ & - & 1704.03 & 189.45 & 12 & 91.22 \\
\hline 12. & $12 \mathrm{FS}_{20}$ & 454.6 & $20 \%$ & 113.7 & 1704.03 & 189.45 & 12 & 91.22 \\
\hline 13. & $12 \mathrm{FS}_{40}$ & 340.9 & $40 \%$ & 227.3 & 1704.03 & 189.45 & 12 & 91.22 \\
\hline 14. & $12 \mathrm{FS}_{60}$ & 227.3 & $60 \%$ & 340.8 & 1704.03 & 189.45 & 12 & 91.22 \\
\hline 15. & $12 \mathrm{FS}_{80}$ & 113.6 & $80 \%$ & 454.5 & 1704.03 & 189.45 & 12 & 91.22 \\
\hline 16. & $14 \mathrm{FS}_{0}$ & 568.3 & $0 \%$ & - & 1704.03 & 189.45 & 14 & 91.22 \\
\hline 17. & $14 \mathrm{FS}_{20}$ & 454.6 & $20 \%$ & 113.7 & 1704.03 & 189.45 & 14 & 91.22 \\
\hline 18. & $14 \mathrm{FS}_{40}$ & 340.9 & $40 \%$ & 227.3 & 1704.03 & 189.45 & 14 & 91.22 \\
\hline 19. & $14 \mathrm{FS}_{60}$ & 227.3 & $60 \%$ & 340.8 & 1704.03 & 189.45 & 14 & 91.22 \\
\hline 20. & $14 \mathrm{FS}_{80}$ & 113.6 & $80 \%$ & 454.5 & 1704.03 & 189.45 & 14 & 91.22 \\
\hline
\end{tabular}

\subsection{Preparation ANd CURING}

Fly ash with silica fume and river sand were mixed thoroughly and dry materials were added slowly in the activating solution prepared by dissolving sodium hydroxide pellets in water and mixing with sodium silicate solution. The mixing was continued until a homogeneous mix was obtained. Several mixes were prepared using fly ash, silica fume and river sand in each experimental series. The geopolymer mortar sample was cast in moulds which were compacted by vibrator machine to remove the entrapped air. After the specimens were cast properly, it was wrapped by plastic sheet 
and left out in ambient temperature for 24 hours and next day it was demoulded. The demoulded specimens were kept in ambient curing until the day of testing.

\subsection{EXPERIMENTAL TESTING}

The mortar specimen's compressive strength was measured by using 70.6 x 70.6 x $70.6 \mathrm{~mm}$ size cube specimens. The compressive strength was determined at the age of 3,7 , and 28 days.Also, the micro structural studies on geopolymer mortar samples which yielded significant compressive strength was examined using X-Ray Diffraction (XRD) and Scanning ElectronMicroscope-Energy Dispersive X-ray Analysis (SEM-EDXA).

\section{RESUlts \& DiscuSSION}

\subsection{COMPRESSIVE STRENGTH OF HCFA GEOPOLYMER MORTAR WITH SILICA FUME As An AdDitive}

The compressive strength results of HCFA geopolymer mortar mixes with different percentage of silica fumeare presented in Table 3.1. From the experimental results, the compressive strength of $8 \mathrm{FS}$ geopolymer mortar ranged from $24.18 \mathrm{MPa}\left(8 \mathrm{FS}_{0}\right)$ to $38.62 \mathrm{MPa}\left(8 \mathrm{FS}_{40}\right)$ at the age of 28 days. The mix $8 \mathrm{FS}_{40}$ has attained higher strength than other mixes made with $8 \mathrm{M} \mathrm{NaOH}$ concentration. The mix $8 \mathrm{FS}_{40}$ achieved a maximum compressive strength of $38.62 \mathrm{MPa}$ at 28 days. It is shown that $40 \%$ silica fume mix $\left(8 \mathrm{FS}_{40}\right)$ imparted $38.7 \%, 52.8 \%$ and $59.7 \%$ higher the compressive strength than $8 \mathrm{FS}_{0}$ at all the age of testing.

The trend observed in compressive strength results of 10FSgeopolymer mortar is almost similar to that of 8FSgeopolymer mortar mixes. However, the compressive strength of 10FSgeopolymer mortar is comparatively higher than the mixes made with 8FSgeopolymer mortar. The compressive strength of $10 \mathrm{FSgeopolymer}$ mortar was ranging from $29.87 \mathrm{MPa}\left(10 \mathrm{FS}_{0}\right)$ to $41.07 \mathrm{MPa}\left(10 \mathrm{FS}_{40}\right)$ at the age of 28 days. Also, it can be seen that $10 \mathrm{FS}_{40}$ produced maximum compressive strength of $41.07 \mathrm{MPa}$ at age of 28 days. It can be noted that the compressive strength of $40 \%$ silica fume mix $\left(10 \mathrm{FS}_{40}\right)$ has gained $37.6 \%, 32 \%$ and $37.1 \%$ higher than the reference mix $10 \mathrm{FS}_{0}$ at the age of 3,7 and 28 days.

The compressive strength of 12FS geopolymer mortar mixes varies from $29.52 \mathrm{MPa}$ $\left(12 \mathrm{FS}_{0}\right)$ to $44.13 \mathrm{MPa}\left(12 \mathrm{FS}_{40}\right)$. It is evident that the range of compressive strength is comparatively 
higher than the mixes made with sodium hydroxide concentration of $8 \mathrm{M}$ and $10 \mathrm{M}$. The mix $12 \mathrm{FS}_{40}$ exhibited the highest compressive strength of $44.13 \mathrm{MPa}$ at 28 days. It is clear that the compressive strength of $40 \%$ silica fume mix $\left(10 \mathrm{FS}_{40}\right)$ has $41 \%, 16.5 \%$ and $21.5 \%$ improvement over reference mix $12 \mathrm{FS}_{0}$ at the age of 3,7 and 28 days.

With respect to 14FSgeopolymer mortar mixes, the compressive strength is observed from36.19MPa $\left(14 \mathrm{FS}_{0}\right)$ to $47.79 \mathrm{MPa}\left(14 \mathrm{FS}_{40}\right)$. It is also evident that compressive strength of 14FSgeopolymer mortar is relatively higher than 8,10 , and $12 \mathrm{M}$ sodium hydroxide concentration mixes. The mix $14 \mathrm{FS}_{40}$ achieved significantly higher compressive strength of $47.79 \mathrm{MPa}$ at the age of 28 days. Further, $14 \mathrm{FS}_{40}$ endorsed $40.7 \%, 27.7 \%$ and $20.5 \%$ more compressive strength at the age of 3,7 and 28 days than the reference mix $14 \mathrm{FS}_{0}$.

The increase in compressive strength of geopolymer incorporating HCFA and silica fume, on the one hand, may be related to denser microstructure systems. [28]Because of the packing effect of the fine silica fume, particles behave as micro-aggregate filler which disperses in geopolymer and fills the inner space inside the microstructure of geopolymer paste [29]. It is also evident that the higher $\mathrm{NaOH}$ concentration resulted higher compressive strength.

Table 3.1. Compressive Strength of HCFA Geopolymer Mortar with Silica Fume as an Additive

\begin{tabular}{|c|c|c|c|c|c|c|c|c|c|c|c|}
\hline \multirow{3}{*}{$\begin{array}{c}\text { Molarity } \\
\text { of } \\
\mathrm{NaOH}\end{array}$} & \multirow{3}{*}{$\begin{array}{l}\text { Mix } \\
\text { ID }\end{array}$} & \multirow{3}{*}{$\begin{array}{c}\text { Replacement } \\
\% \text { of Silica } \\
\text { Fume }\end{array}$} & \multicolumn{9}{|c|}{ Compressive Strength (MPa) } \\
\hline & & & \multicolumn{3}{|c|}{3 days } & \multicolumn{3}{|c|}{7 days } & \multicolumn{3}{|c|}{28 days } \\
\hline & & & Mean & STDEV & $\mathrm{COV}$ & Mean & STDEV & $\mathrm{COV}$ & Mean & STDEV & $\mathrm{COV}$ \\
\hline \multirow{5}{*}{8} & $8 \mathrm{FS}_{0}$ & $0 \%$ & 11.90 & 0.04 & 0.34 & 19.34 & 0.05 & 0.26 & 24.18 & 0.21 & 0.87 \\
\hline & $8 \mathrm{FS}_{20}$ & $20 \%$ & 15.63 & 0.62 & 3.97 & 26.14 & 0.84 & 3.21 & 33.78 & 0.54 & 1.60 \\
\hline & $8 \mathrm{FS}_{40}$ & $40 \%$ & 16.50 & 0.04 & 0.24 & 29.56 & 0.05 & 0.17 & 38.62 & 0.31 & 0.80 \\
\hline & $8 \mathrm{FS}_{60}$ & $60 \%$ & 13.92 & 0.19 & 1.36 & 24.53 & 0.27 & 1.10 & 35.24 & 0.97 & 2.75 \\
\hline & $8 \mathrm{FS}_{80}$ & $80 \%$ & 11.05 & 0.17 & 1.54 & 18.17 & 0.41 & 2.26 & 27.32 & 0.77 & 2.82 \\
\hline \multirow{5}{*}{10} & $10 \mathrm{~F} \mathrm{~S}_{0}$ & $0 \%$ & 14.18 & 0.08 & 0.56 & 23.04 & 0.15 & 0.65 & 29.95 & 0.29 & 0.97 \\
\hline & $10 \mathrm{FS}_{20}$ & $20 \%$ & 17.08 & 0.06 & 0.35 & 28.95 & 0.73 & 2.52 & 39.02 & 0.65 & 1.67 \\
\hline & $10 \mathrm{FS}_{40}$ & $40 \%$ & 19.51 & 0.05 & 0.26 & 30.41 & 0.02 & 0.07 & 41.07 & 0.58 & 1.41 \\
\hline & $10 \mathrm{FS}_{60}$ & $60 \%$ & 16.93 & 0.65 & 3.84 & 25.87 & 0.37 & 1.43 & 37.59 & 0.82 & 2.18 \\
\hline & $10 \mathrm{FS}_{80}$ & $80 \%$ & 13.52 & 0.1 & 0.74 & 21.93 & 0.01 & 0.05 & 29.87 & 0.71 & 2.38 \\
\hline \multirow{5}{*}{12} & $12 \mathrm{~F} \mathrm{~S}_{0}$ & $0 \%$ & 15.35 & 0.31 & 2.02 & 27.8 & 0.36 & 1.29 & 36.31 & 0.62 & 1.71 \\
\hline & $12 \mathrm{FS}_{20}$ & $20 \%$ & 17.94 & 0.57 & 3.18 & 29.91 & 0.72 & 2.41 & 38.12 & 0.14 & 0.37 \\
\hline & $12 \mathrm{FS}_{40}$ & $40 \%$ & 21.65 & 0.75 & 3.46 & 32.38 & 0.18 & 0.56 & 44.13 & 0.79 & 1.79 \\
\hline & $12 \mathrm{FS}_{60}$ & $60 \%$ & 16.93 & 0.16 & 0.95 & 26.75 & 0.58 & 2.17 & 37.72 & 0.22 & 0.58 \\
\hline & $12 \mathrm{FS}_{80}$ & $80 \%$ & 14.18 & 0.09 & 0.63 & 23.86 & 0.54 & 2.26 & 29.52 & 0.51 & 1.73 \\
\hline \multirow{5}{*}{14} & $14 \mathrm{~F} \mathrm{~S}_{0}$ & $0 \%$ & 16.56 & 0.24 & 1.45 & 27.87 & 0.77 & 2.76 & 39.65 & 0.84 & 2.12 \\
\hline & $14 \mathrm{FS}_{20}$ & $20 \%$ & 18.74 & 0.02 & 0.11 & 29.15 & 0.62 & 2.13 & 40.97 & 0.41 & 1.00 \\
\hline & $14 \mathrm{FS}_{40}$ & $40 \%$ & 23.30 & 0.12 & 0.52 & 35.59 & 0.11 & 0.31 & 47.79 & 0.01 & 0.02 \\
\hline & $14 \mathrm{FS}_{60}$ & $60 \%$ & 20.63 & 0.14 & 0.68 & 32.98 & 0.95 & 2.88 & 41.63 & 0.07 & 0.17 \\
\hline & $14 \mathrm{FS}_{80}$ & $80 \%$ & 17.18 & 0.35 & 2.04 & 26.74 & 0.65 & 2.43 & 36.19 & 0.63 & 1.74 \\
\hline
\end{tabular}

\footnotetext{
Note: $\mathrm{STDEV}=$ Standard Deviation, $\mathrm{COV}=$ Coefficient of Variance [\%]
} 


\subsubsection{The Mathematical Regression Model}

Based on experimental results, mathematical models for compressive strength and various percentage of silica fume is developed using polynomial regression equation.

\section{Compressive Strength Prediction Model for various Silica fume Percentages}

The model consists of parameters Silica fume content percentage (denoted by s), Compressive strength of specimen in $8 \mathrm{M}$ concentration at 3,7 , and 28 days (denoted by $8 \mathrm{fc}_{3}, 8 \mathrm{fc}_{7}$, and $8 \mathrm{fc}_{28}$ respectively). Figure 3.1(a) shows the equations (gradients) of compressive strength for five mortar mixes $\left(8 \mathrm{FS} 0,8 \mathrm{FS}_{20}, 8 \mathrm{FS}_{40}\right.$, $\left.8 \mathrm{FS}_{60}, 8 \mathrm{FS}_{80}\right)$ at various silica fume replacements, and the corresponding coefficient of determination $\left(R^{2}\right)$ or correlation coefficient $(R)$. Correlation coefficient $(R)$ for all the curves is closer to unity, indicating that the polynomial second order equation is found to fit well. The first factor considered was silica fume percentage. According to silica fume content in $8 \mathrm{M}$ of $\mathrm{NaOH}$, the compressive strength results of 3, 7, and 28 days the regression equation was proposed in Eqn. (1.a),(1.b), and (1.c))

$$
\begin{aligned}
& 8 \mathrm{fc}_{3}=-29.69642857 \mathrm{~s}^{2}+22.04214286 \mathrm{~s}+12.10628571 ; \mathrm{R}^{2}=0.96 \\
& 8 \mathrm{fc}_{7}=-62.08928571 \mathrm{~s}^{2}+47.69642857 \mathrm{~s}+19.37085714 ; \mathrm{R}^{2}=0.97 \\
& 8 \mathrm{fc}_{28}=-77.25 \mathrm{~s}^{2}+65.67 \mathrm{~s}+24.1 ; \mathrm{R}^{2}=0.99
\end{aligned}
$$

Figure 3.1(b) shows the equations of compressive strength for geopolymer mortar mixes $\left(10 \mathrm{FS}, 10 \mathrm{FS}_{20}\right.$, $10 \mathrm{FS}_{40}, 10 \mathrm{FS}_{60}, 10 \mathrm{FS}_{80}$ ) for various silica fume replacement percentage. At $10 \mathrm{M}$ concentration of $\mathrm{NaOH}$, the compressive strength results for various percentage of silica fume was predicted by the following Eqn. (2.a), (2.b), and (2.c). Similarly for $12 \mathrm{M}$ and $14 \mathrm{M}$ concentration of $\mathrm{NaOH}$ the corresponding compressive strength results for 3,7,28 days was calculated by the regression Eqn.(3.a),(3.b), and (3.c) and Eqn.(4.a),(4.b), and (4.c) respectively. Fig 3.1(c) and Fig 3.1(d) represents the regression model predicted for the compressive strength for $12 \mathrm{M}$ and $14 \mathrm{M}$ concentration of $\mathrm{NaOH}$ mortar specimens.

$$
\begin{aligned}
& 10 \mathrm{fc}_{3}=-31.48214286 \mathrm{~s}^{2}+24.45071429 \mathrm{~s}+14.01942857 ; \mathrm{R}^{2}=0.95 \\
& 10 \mathrm{fc}_{7}=-45.89285714 \mathrm{~s}^{2}+34.06428571 \mathrm{~s}+23.42857143 ; \mathrm{R}^{2}=0.93 \\
& 10 \mathrm{fc}_{28}=-69.83928571 \mathrm{~s}^{2}+55.07642857 \mathrm{~s}+30.23085714 ; \mathrm{R}^{2}=0.99 \\
& 12 \mathrm{fc}_{3}=519.53125 \mathrm{~s}^{4}-822.3958333 \mathrm{~s}^{3}+361.96875 \mathrm{~s}^{2}-30.70416667 \mathrm{~s}+15.35 ; \mathrm{R}^{2}=1 \\
& 12 \mathrm{fc}_{7}=502.6041667 \mathrm{~s}^{4}-779.375 \mathrm{~s}^{3}+331.3958333 \mathrm{~s}^{2}-28.575 \mathrm{~s}+27.8 ; \mathrm{R}^{2}=1 \\
& 12 \mathrm{fc}_{28}=709.6354167 \mathrm{~s}^{4}-1197.8125 \mathrm{~s}^{3}+572.4895833 \mathrm{~s}^{2}-63.2125 \mathrm{~s}+36.31 ; \mathrm{R}^{2}=1 \\
& 14 \mathrm{fc}_{3}=418.229166 \mathrm{~s}^{4}-702.0833333 \mathrm{~s}^{3}+333.8958333 \mathrm{~s}^{2}-31.14166667 \mathrm{~s}+16.56 ; \mathrm{R}^{2}=1 \\
& 14 \mathrm{fc}_{7}=511.1979167 \mathrm{~s}^{4}-909.4791667 \mathrm{~s}^{3}+467.0520833 \mathrm{~s}^{2}-54.720833 \mathrm{~s}+27.87 ; \mathrm{R}^{2}=1 \\
& 14 \mathrm{fc}_{28}=838.0208333 \mathrm{~s}^{4}-1390.625 \mathrm{~s}^{3}+668.4791667 \mathrm{~s}^{2}-78.175 \mathrm{~s}+39.65 ; \mathrm{R}^{2}=1
\end{aligned}
$$




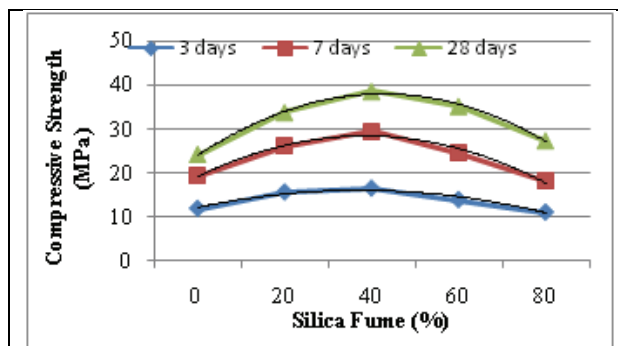

a) $8 \mathrm{M}$

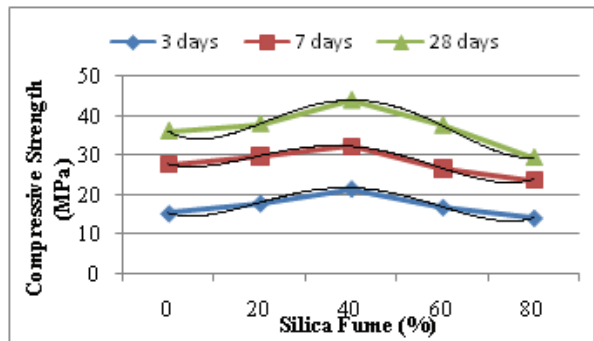

c) $12 \mathrm{M}$

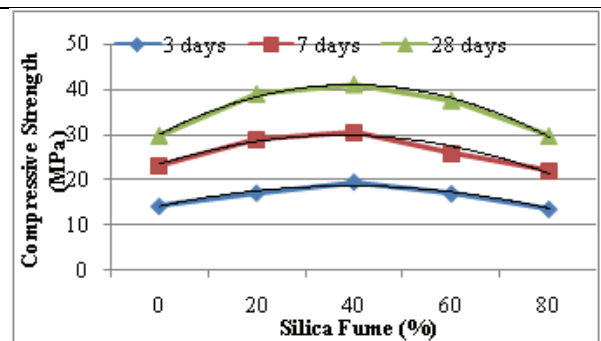

b) $10 \mathrm{M}$

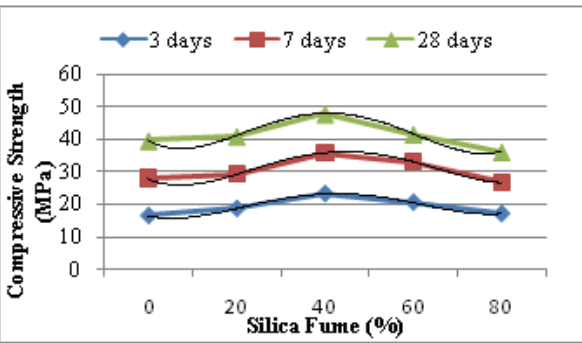

d) $14 \mathrm{M}$

Fig. 3.1 Relationship between Compressive Strength of HCFA Geopolymer Mortar and NaOH concentration

\section{Compressive Strength Prediction Model For VARIOUS SOdium hydroxide} CONCENTRATIONS

The mathematical model was also created by analysing the parameters molar concentration of $\mathrm{NaOH}$ (denoted by $\mathrm{N}$ ) and compressive strength (fc) for various the percentage of silica fume. Where fc is the polynomial regression equation considering the effect of molar concentration of $\mathrm{NaOH}$; the predicted results for $0 \%$ silica fume mortar mixes $\left(8 \mathrm{FS}_{0}, 10 \mathrm{FS}_{0}, 12 \mathrm{FS}_{0}, 14 \mathrm{FS}_{0}\right)$ are shown in Fig. 3.2(a). It was found that the value of correlation coefficient was near to 1 , which means this mathematical model can predict the 3,7 , and 28 day compressive strength with very high accuracy due to the selection of appropriate equations. According to silica fume content, the compressive strength results for various molar concentration of $\mathrm{NaOH}$ is presented in Eq. (5.a), Eq. (5.b) and Eq. (5.c) for 3, 7, and 28 day compressive strength of geopolymer mortar for the specimens without silica fume content.

Fig 3.2(b) shows the compressive strength results for $20 \%$ silica fume content for mortar cubes, corresponding regression equation is denoted in Eq. (6.a), Eq. (6.b) and Eq. (6.c). Similarly for 40\%, 60\% and $80 \%$ silica fume contents mixes, the mathematical model is shown in Fig 3.2(c), Fig 3.2(d) and Fig 3.2(e). Corresponding regression equation for compressive strength is denoted in Eq. (7.a), Eq. (7.b) and Eq. (7.c), Eq. (8.a), Eq. (8.b) and Eq. (8.c), (9.a), Eq. (9.b) and Eq. (9.c). 


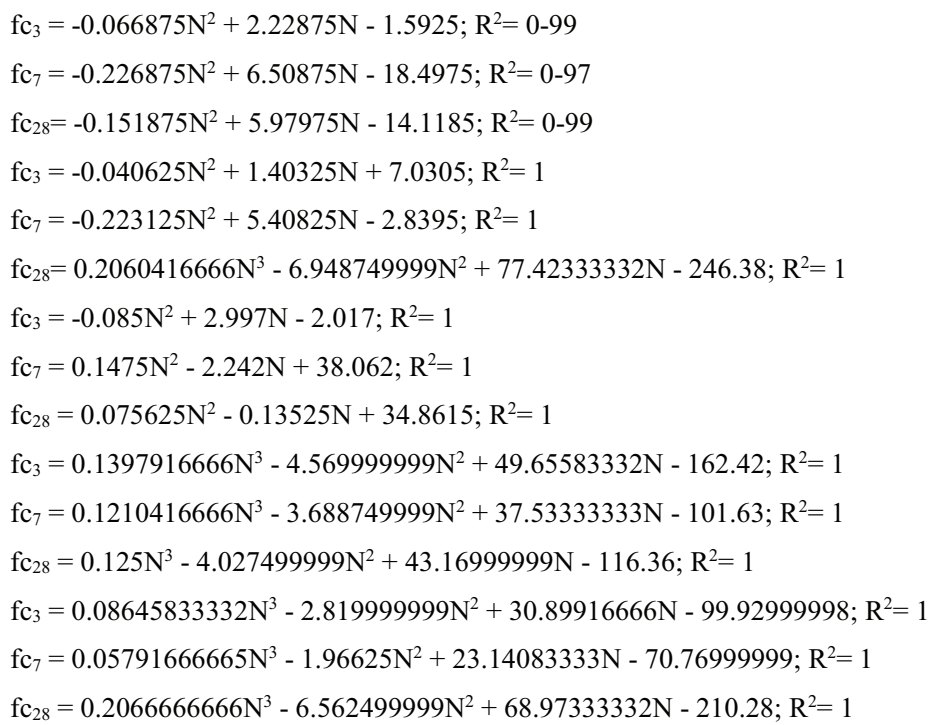

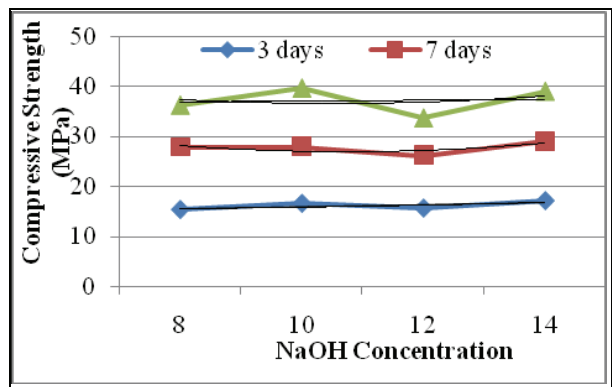

a) $0 \%$ Silica Fume

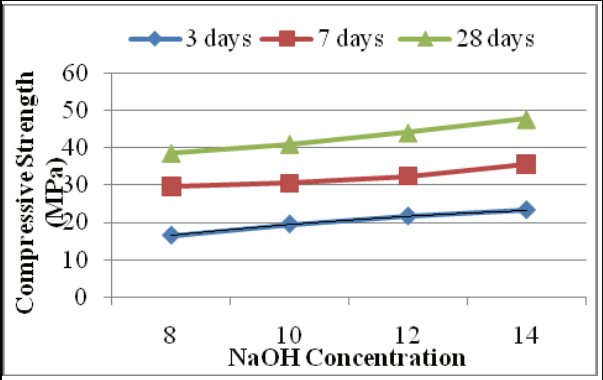

c) $40 \%$ Silica Fume

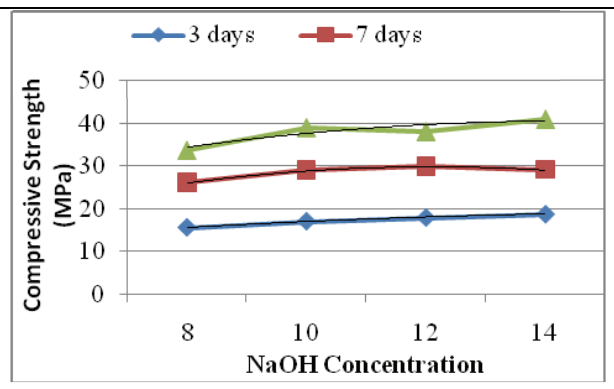

b) $20 \%$ Silica Fume

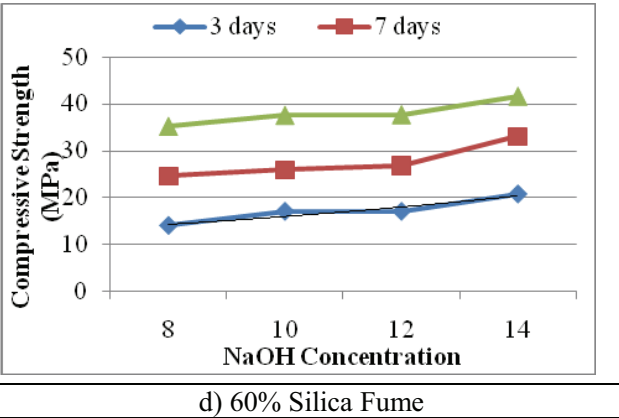




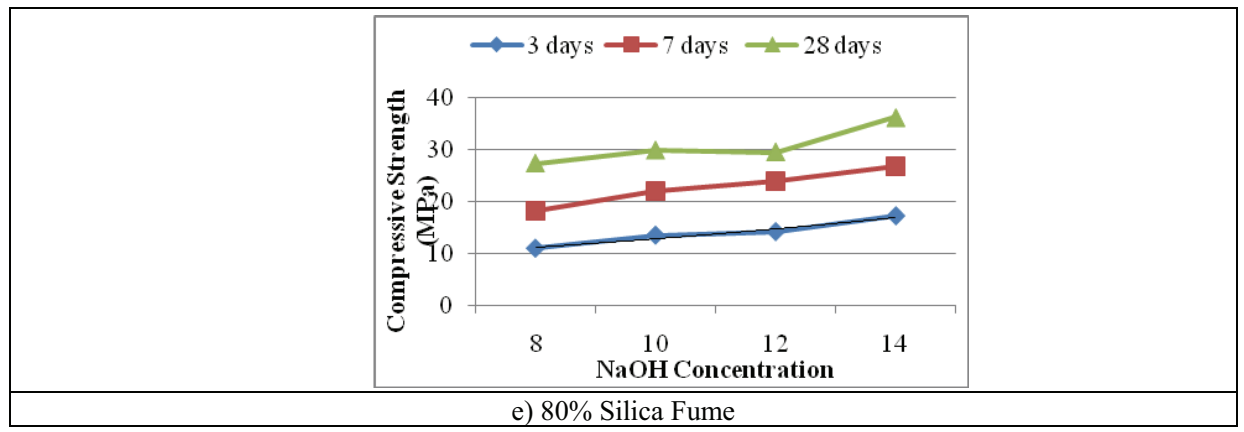

Fig. 3.2 Relationship between Compressive Strength of HCFA Geopolymer Mortar and Silica Fume

\subsection{Micro STRUCTURAL ANALYSIS}

The higher compressive strength produced specimens were chosen to scan the microstructure and to understand the mechanism of geopolymeric reaction. Scanning Electron Microscope (SEM) with EDAX analysis and X-Ray Diffraction (XRD) were performed for geopolymer mortar powdered sample $14 \mathrm{FS}_{0}$ mix containing $100 \%$ HCFA, $14 \mathrm{FS}_{40}$ mix containing $40 \%$ silica fume and $60 \%$ HCFA collected at the age of 28 days. The samples were ground to fine powder for micro structural analysis.

\subsubsection{XRD ANALYSIS}

The XRD analysis results for the mortar specimens $14 \mathrm{FS} \mathrm{S}_{0}\left(100 \%\right.$ HCFA), $14 \mathrm{FS} \mathrm{S}_{40}$ (40\% silica fume, $60 \%$ HCFA) are shown in Fig. 3.3 and 3.4. In the present work, HCFA geopolymer mortar specimen $\left(14 \mathrm{FS}_{0}\right)$ has the $\mathrm{X}$ - ray diffraction $(\mathrm{XRD})$ as shown in Fig 3.3 with huge scattered peak ranging from $20-30^{\circ}(2 \theta$ max $)$. It endorses the existence of quartz, calcite, and anatase in the matrix. Alkaline activators formed major amorphous phase in HCFA geopolymer.XRD pattern presented in Fig. 3.4 depicts the spectrum of geopolymer mortar prepared with $60 \%$ HCFA and $40 \%$ silica fume $\left(14 \mathrm{FS}_{40}\right)$. The X-ray diffraction (XRD) spectra illustrates that it has huge scattered peak ranging from $20-30^{\circ}(2 \theta$ max). The major crystalline peak represents the compounds such as quartz, calcite, hematite, boetimite, and hornblende and anatase formation in the matrix. The additional compounds formations are higher in $14 \mathrm{FS}_{40}$ than reference $14 \mathrm{FS}_{0}$. The strength enhancement is evidenced due to the additional compounds formation. Further, the diffractogram indicates minor crystalline phase structure and major amorphous phase similar to $14 \mathrm{FS}_{0}$. 


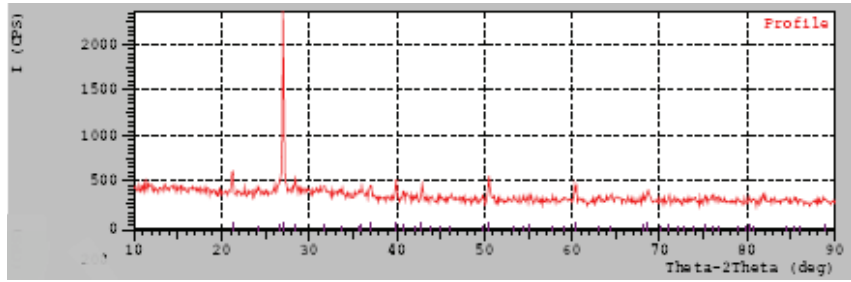

Fig.3.3 X-Ray Diffractogram of Fly ash Geopolymer Mortar 100\% HCFA (14FS 0 )

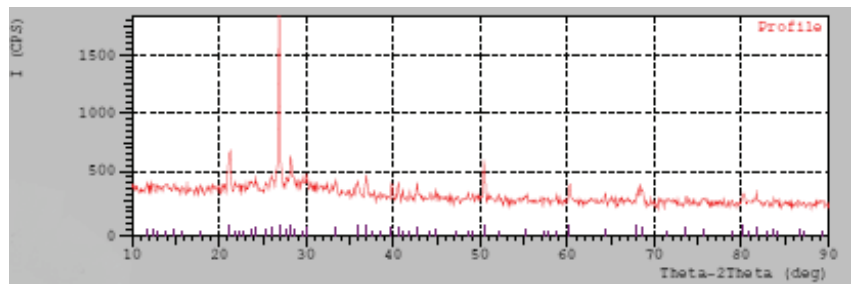

Fig.3.4 X-Ray Diffractogram of Geopolymer Mortar 60\% HCFA, 40\% silica fume (14FS 40$)$

\subsubsection{SEM- EDAX ANALYSIS}

The presence of C-A-S-H gel, N-A-S-H gel and hydroxysodalite gel products are identified in both $14 \mathrm{FS}_{0}$ and $14 \mathrm{FS}_{40}$ mix sample micrographs as shown in Fig 3.5 and 3.6. Further, the presence of voids is visible in $14 \mathrm{FS}_{0}$ mix sample. However, the incorporation of silica fume filled the voids and has shown much denser microstructure. The formation of additional gel products due to the incorporation of silica fume particles led to a compact microstructure and enhanced the strength[30].Thus, it can be stated that the silica fume could increase the strength properties of geopolymer.

EDAX spectrum of $14 \mathrm{FS}_{0}$ and $14 \mathrm{FS}_{40}$ mix sample is given in Fig 3.5 and 3.6. The result confirms that elements such as silica, alumina, calcium, magnesium, sodium and iron are the dominating elements present in geopolymer mortar. 

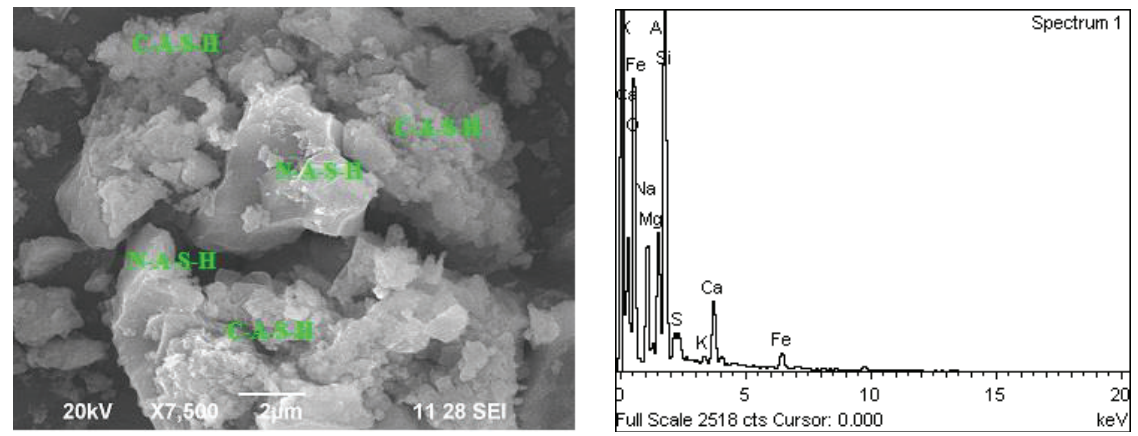

Fig.3.5. SEM-EDAX image of specimen $14 \mathrm{FS}_{0}$, mortar cube $14 \mathrm{M}$ of $\mathrm{NaOH}, 100 \% \mathrm{HCFA}$
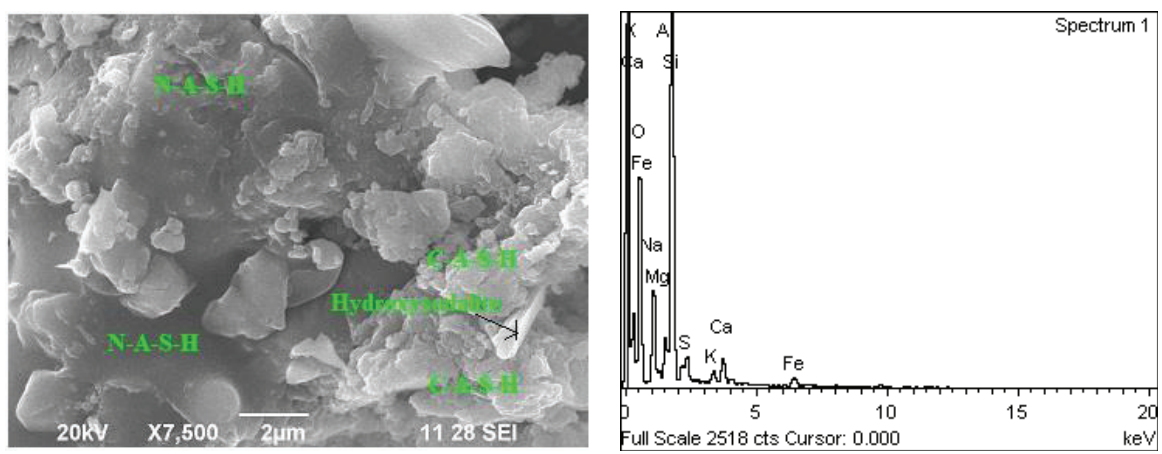

Fig.3.6. SEM-EDAX image of specimen $14 \mathrm{FS}_{40}$, mortar cube $14 \mathrm{M}$ of $\mathrm{NaOH} 40 \%$ Silica fume $60 \% \mathrm{HCFA}$

\section{CONCLUSION}

In this study on HCFA based geopolymer mortar incorporating silica fume, the following conclusions are drawn.

Geopolymer mortar mixes produced noticeably higher compressive strength at all ages at ambient curing temperature when sodium hydroxide concentration was14M. When $\mathrm{NaOH}$ molar concentration was increased, the compressive strength of specimens was augmented by $18.4 \%$, $28.5 \%$, and $38.6 \%$ for $10 \mathrm{M}, 12 \mathrm{M}$ and $14 \mathrm{M}$ respectively. The addition of silica fume with HCFA increased the compressive strength of mortar specimens in all the four molar concentrations of $\mathrm{NaOH}(8 \mathrm{M}, 10 \mathrm{M}, 12 \mathrm{M}$, and $14 \mathrm{M})$ in the range of $20-58 \%$. This is because of the filler effect of the silica fume and denseness of the alkaline liquid. However, silica fume content beyond $40 \%$ results in decreasing the compressive strength of mortar specimens. At $8 \mathrm{M}$ concentration of $\mathrm{NaOH}$ the maximum compressive strength of $38.62 \mathrm{MPa}$ was obtained for $40 \%$ replacement of silica fume 
(8FS40). For every $2 \mathrm{M}$ interval the same $40 \%$ silica fume specimen attained its maximum compressive strength of $41.07 \mathrm{MPa}, 44.13 \mathrm{MPa}$ and $47.79 \mathrm{MPa}$ for the mixes $10 \mathrm{FS}_{40}, 12 \mathrm{FS}_{40}$ and $14 \mathrm{FS}_{40}$ respectively. The mix containing $14 \mathrm{FS}_{40}$ having $60 \%$ HCFA and $40 \%$ silica fume achieved higher compressive strength of $47.79 \mathrm{MPa}$ compared to all other mixes studied.

XRD Diffractogram analysis of geopolymer mortar indicates minor crystalline phase and major amorphous phase. More mineral compounds such as quartz, calcite, hematite, boetimite, hornblende and anatase formed in the matrix contributed higher strength in the $14 \mathrm{FS}_{40}$. SEM micrograph indicates that HCFA with silica fume demonstrated dense and compact structure with more C-A-S-H gel, N-A-S-H gel and hydroxysodalite gel products and imparting significant gain in compressive strength.

\section{References}

1. Prakash R. Voraa, Urmil V. Dave,"Parametric Studies on Compressive Strength of Geopolymer Concrete", Procedia Engineering 51:210 - 219, 2013.

2. Mohammed BS, Fang OC, "Mechanical and durability properties of concretes containing paper-mill residuals and fly ash", Construction and Building Materials 25:717-725, 2011.

3. Lateef N. Assi, Edward (Eddie) Deaver, Mohamed K. El Batanouny, Paul Ziehl, "Investigation of early compressive strength of fly ash-based geopolymer Concrete", Construction and Building Materials 112: 807$815,2016$.

4. Daniel L.Y. Kong, Jay G. Sanjayan, Kwesi Sagoe-Crentsil, "Comparative performance of geopolymers made with metakaolin and fly ash after exposure to elevated temperatures", Cement and Concrete Research37: 1583-1589, 2007.

5. Prakash R. Vora, Urmil V. Dave, "Parametric Studies on Compressive Strength of Geopolymer Concrete", Procedia Engineering 51: 210 - 219, 2013.

6. Rohit Zende, Mamatha. A, "Study on Fly Ash and GGBS Based Geopolymer Concrete under Ambient Curing”, Journal of Emerging Technologies and Innovative Research 2 (7) (2015) 3082-3087.

7. Shadi Riahi, Ali Nazari, "The effects of nanoparticles on early age compressive strength of ash-based geopolymers", Ceramics International 38: 4467-4476, 2012.

8. Partha Sarathi Deb, Pradip Nath, Prabir Kumar Sarker, "The effects of ground granulated blast-furnace slag blending with fly ash and activator content on the workability and strength properties of geopolymer concrete cured at ambient temperature", Materials and Design (2014), doi: http://dx.doi.org/10.1016/j.matdes.2014.05.001.

9. Chien-Chung Chen, Ivan Diaz, Kathleen Menozzi, Luis Murillo, “An experimental study on slag/fly ash-based geopolymer concrete", Proceedings of ISER 11th International Conference, San Francisco, USA, 26-30, 2015.

10. Ashley Russell Kotwal, Yoo Jae Kim, Jiong Hu, Vedaraman Sriraman, "Characterization and Early Age Physical Properties of Ambient Cured Geopolymer Mortar Based on Class C Fly Ash", International Journal of Concrete Structures and Materials 9 (1): 35-43, 2015.

11. J. Temuujin, R.P.Williams, A. van Riessen, "Effect of mechanical activation of fly ash on the properties of geopolymer cured at ambient temperature”, Journal of Materials Processing Technology 209: 5276-5280, 2009.

12. B. Vijaya Rangan, "Fly Ash-Based Geopolymer Concrete, Proceedings of the International Workshop on Geopolymer Cement and Concrete", Allied Publishers Private Limited, Mumbai, India, 68-106, 2010.

13. Xueying Li, Xinwei Ma, Shoujie Zhang, Enzu Zheng, "Mechanical Properties and Microstructure of Class C Fly Ash-Based Geopolymer Paste and Mortar", Materials 6: 1485-1495, 2013. doi:10.3390/ma6041485.

14. Guo, X.L. Shi, H.S. Dick, W.A, "Compressive strength and microstructural characteristics of class C fly ash geopolymer", Cement Concrete Composites 32: 142-147, 2010.

15. KolliRamujee, Potharaju.M, "Development of Low Calcium Flyash Based Geopolymer Concrete", IACSIT International Journal of Engineering and Technology 6(1): 1-4, 2014.

16. R.Manickavasagam, G.Mohan kumar, "Short term properties of High Calcium Flyashbased Geopolymer binder", IOSR Journal of Mechanical and Civil Engineering 14 (1) III: 13-20, Jan. - Feb. 2017. 
17. V.Revathi, R.Saravanakumar, J.Thaarrini, "Effect of molar ratio of $\mathrm{SiO}_{2} / \mathrm{Na}_{2} \mathrm{O}, \mathrm{Na}_{2} \mathrm{SiO}_{3} / \mathrm{NaOH}$ ratio and curing mode on the compressive strength of ground bottom ash geopolymer mortar", International Journal of Earth Sciences and Engineering 7 (4): 1511-1516, 2014.

18. Eslam Gomaa, Simon Sargon, Cedric Kashosi, Mohamed ElGawady, "Fresh properties and compressive strength of high calcium alkali activated fly ash mortar", Journal of King Saud University - Engineering Sciences 29: 356-364, 2017.

19. Xiaolu Guo, Huisheng Shi, Warren A. Dick, "Compressive strength and micro-structural characteristics of class C fly ash Geopolymer", Cement \& Concrete Composites, 32: 142-147, 2010.

20. Kong, D.L.Y, Sanjayan, J.G, "Effect of elevated temperatures on geopolymer paste, mortar and concrete", Cement Concrete Research40: 334-339, 2010.

21. Manjunath S. Sontakki, Swapnil B. Cholekar, "Strength Performance Studies on Ambient Cured Silica fume based Geopolymer Concrete", International Research Journal of Engineering and Technology 2(7): e-ISSN: 2395 -0056, p-ISSN: 2395-0072, 2015.

22. D.R.M. Brew, K.J.D. MacKenzie, "Geopolymer synthesis using silica fume and sodium aluminate", Journal of Material Sciences, 42: 3990-3993, 2007.

23. Khater HM, El-Sabbagh BA, Fanny M, Ezzat M, Lottfy M, "Effect of nano-silica on alkali activated water cooled slag geopolymer", ARPN Journal of Engineering and Applied Sciences 2 (2012) 170-176.

24. Riahi S, Nazari A, "The effects of nano particles on early age compressive strength of ash-based geopolymers", Ceramics International 38: 4467-76, 2012.

25. Ping Duan, Chunjie Yan, Wei Zhou, "Compressive strength and microstructure of fly ash based geopolymer blended with silica fume under thermal cycle", Cement and Concrete Composites 78 (2017) 108- 119.

26. Antonia, Lucky Chandraa, Djwantoro Hardjitoa, "The impact of using fly ash, silica fume and calcium carbonate on the workability and compressive strength of mortar", Procedia Engineering 125: 773 - 779, 2015.

27. M. Rostami, K. Behfarnia, "The effect of silica fume on durability of alkali activated slag concrete", Construction and Building Materials 134: 262-268, 2017.

28. Suresh Thokchom, Debabrata Dutta, Somnath Ghosh, "Effect of Incorporating Silica Fume in Fly Ash Geopolymers, International Journal of Civil and Environmental Engineering 5(12): 750-754, 2011.

29. F.N. Okoye, J. Durgaprasad, N.B. Singh, "Effect of silica fume on the mechanical properties of fly ash basedgeopolymer concrete", Ceramics International, http://dx.doi.org/10.1016/j.ceramint.2015.10.084

30. A.M. Rashad, S.R. Zeedan, "A preliminary study of blended pastes of cement and quartz powder under the effect of elevated temperature", Construction Building Materials 29: 672-681, $2012 .$.

\section{LIST OF FIGURES AND TABLES:}

Tab. 2.1.Chemical composition of fly ash and Silica fume

Tab. 2.2.Mix Proportions of High Calcium Geopolymer mortar with Silica Fume

Tab. 3.1.Compressive Strength of HCFA Geopolymer Mortar with Silica Fume as an Additive

Fig. 3.1 Relationship between Compressive Strength of HCFA Geopolymer Mortar and $\mathrm{NaOH}$ concentration

Fig. 3.2 Relationship between Compressive Strength of HCFA Geopolymer Mortar and Silica Fume

Fig.3.3.X-Ray Diffractogram of Fly ash Mortar 100\% HCFA (14FS ${ }_{0}$ )

Fig.3.4.X-Ray Diffractogram of Mortar 60\% HCFA, 40\% silica fume (14FS 40 )

Fig. 3.5.SEM-EDAX image of specimen $14 \mathrm{FS}_{0}$, mortar cube $14 \mathrm{M}$ of $\mathrm{NaOH}, 100 \%$ HCFA

Fig. 3.6.SEM-EDAX image of specimen $14 \mathrm{FS}_{40}$, mortar cube $14 \mathrm{M}$ of $\mathrm{NaOH} 40 \%$ Silica fume $60 \%$ HCFA 